\title{
Historicising the Question of Democra- cy's Presentism: The Concept of Interest and Political Languages of the Future in France, 1830-1850
}

Julia Nordblad, University of Uppsala

\begin{abstract}
A long-standing allegation holds that democracy is inherently biased in favour of the present to the detriment of the future. In this article, I question this premise by looking at temporality as a contested aspect of democratic practices of legitimisation. I approach democracy as a fundamentally historical phenomenon with language-based practices at its core. This is done through an examination of parliamentary debates on long-term policies on forests in the 1830s and 40s in France. In this context, there was a struggle over temporality that was played out as a conflict over the concept of interest. This article suggests an examination of the concept of interest as a locus for contestation between competing political languages implying different temporalities as a way of understanding democracy historically. The development of a concept of interest with the long term at its core in the late $1840 \mathrm{~s}$ can be seen as a redescription of key concepts established as part of the radical Enlightenment political program of presentism. Following this analysis, I argue that democracy is not inherently presentist, but is shaped by a history in which both languages of radical presentism and elaborate long-term perspectives are constitutive parts. As such, these languages make up resources for developing legitimacy for long-term policies in contemporary democracies.
\end{abstract}

Keywords: Democracy, presentism, future generations, interest, conceptual history, July monarchy, France, forest policy, long-termism 


\section{Is Democracy Presentist?}

Political theorists, often with an interest in issues of environmental degradation and climate change, have treated a problem they identify as a temporal bias in democracy as a political system (in addition to the works cited below, see also Beckman, 2008; 2015; Skagen Ekeli, 2005; 2006). The climate effects of emissions occur with a significant delay, and current politicians and voters can therefore be tempted to defer costs and efforts needed to limit this type of problems into the future (Gardiner, 2014: 301). As Dennis F. Thompson has phrased it, "democracy is prone to what may be called presentism - a bias in the laws in favour of present over future generations" (Thompson, 2010: 17). This bias, often referred to as democracy's myopia, is described as inherent or systematic, as a feature tied to the defining characteristics of democracy (Thompson, 2005: 246; Rosanvallon, 2014: 836ff; Keane, 2016). I will in the following refer to this problem as democracy's presentism.

Political theorists have suggested different kinds of solutions to this problem of democracy's presentism, such as special commissioners or parliamentary seats designated to represent or protect the interest of future generations (for an overview of some of these suggestions, see Beckman, 2013: 777; 2015: 518; see also González-Ricoy and Gosseries (eds.), 2016; Rosanvallon, 2014: $840 \mathrm{ff}$ ). For some theorists however, the presentist temporality is closely intertwined with, or even essential to, democracy as a political system, and the problem is therefore difficult to solve. Ludvig Beckman for example describes and concurs with what he cites as a classic conception that "each generation has the power to amend constitutions and to enact new laws and that, consequently, there are no legal precepts introduced by the past (or by the present) that cannot be revoked by the present (or by the future). Generations cannot rule one another" (Beckman, 2013: 786). Reconciling long-term perspectives with democratic rule is therefore problematic: "representing the interests of future generations in political decisions is not consistent with securing democracy for the living generation" (Beckman, 2013: 775).

\section{Democracy's Presentism in French Revolutionary Thought}

In this article, I propose an alternative to the analytic political-theoretical approach to the problem of democracy's presentism, namely a historical one. An initial step in such an approach is to examine what it means that presentism, in the sense of a disqualification of long-term political measures, was once part of a political program. The radical break with the long-term and with previous and future generations was a way for many 18 th century revolutionaries to 
imagine political renewal. Especially the French and American revolutionaries constructed their break with the old regime in a way that made necessary the disqualification of any right of the present to subject future generations to its laws (Willer, 2011: 72). This programmatic presentism meant a strong discrediting of transgenerational bonds in general. After all, the decapitation of royal power was a radical refusal of hereditary power, and subsequently, a brother society replaced a father society in which transgenerational bonds were essential to political legitimacy (Hunt, 1992).

Starting at the end of the 18 th century, political renewal was frequently conceptualised in generational terms (Parnes et al., 2008: 82). The trope of a revolt of the young against the old was inherent in the revolutionary political model, and the revolutions of 1789 and 1830, were often understood in precisely that generational way. Radical writers and politicians celebrated the generational break as a force of political renewal and legitimacy (Nora, 1992: 940-43; Sahlins, 1994: 119). The break with old regime temporality was a central and concrete task for the revolutionaries. They proclaimed year zero and created a new calendar of months and days, a move that Russian revolutionaries would imitate over a century later (Velicu, 2010: 90). The idea was widely held that longterm political claims were illegitimate as future generations were sovereign in their own right. Jean-Jacques Rousseau, a standard reference and source of legitimacy for the Jacobins (Jaume, 1992), famously wrote that it is absurd for the sovereign to "give itself fetters for the future" (Rousseau, 1988 [1762]: 99). The political independence of each new generation was also central to political philosophers like Condorcet, and this left a lasting legacy: his formula that "one generation doesn't have the right to subject to its law the future generations" was enshrined in article 28 of the 1793 Declaration of the rights of man and citizen. The view that political claims across generations were problematic and illegitimate was also reflected in the heated debates on inheritance, and its abolition during the French revolution (Parnes et al., 2008: 97, 102-105; Nora, 1992: 933). At this point in democracy's history, programmatic presentism was regarded as a virtue by many political thinkers. This was however a function of a specific historical moment, one in which the historical circumstances made the generational break crucial to political renewal. The fact that monarchical power was fundamentally generational was one such important circumstance.

In the political debate during and after the French revolution, the idea to include future generations in the political community was promoted by conservative critics of the revolution, such as Edmund Burke. In Reflections on the Revolution in France, he envisioned future generations as well as the dead as part of the same political community as the living (Burke, 2001[1790]: 261; Nedevska Törnqvist, 2010: 37; see also Parnes et al., 2008: 99-100 for examples of conservative uses of the generation model in German). Arguing against 46 
this in what was to become an iconic dispute, Thomas Paine stated that "every age and generation must be as free to act for itself in all cases as the age and generations which preceded it. The vanity and presumption of governing beyond the grave is the most ridiculous and insolent of all tyrannies" (Paine, 1996 [1791]: 9).

But the proponents of political revolution were also concerned with establishing traditions and projecting their political project on to future generations. Some historians have regarded their repeated calls for regeneration and breaks with the established order as almost hypocritical in the sense that it was really about the opposite of regeneration, namely transfer, about continuity instead of breaks (Velicu, 2010: 3). It is not necessary to go that far to recognise that there was a certain ambivalence to the radical thoughts of necessary generational breaks. The French revolutionaries also established practices of political projections into the future, such as the planting of so-called trees of liberty, a clearly transgenerational act of political symbolism for the long-lasting regeneration of the nation (Pacini, 2016: 176). Interestingly, this symbol was taken up during all the subsequent revolutions of the nineteenth century, not least in 1848 (Fechner, 1987: 41).

As it turns out, the idea that democracy cannot be transgenerational without ceasing to be democratic was launched as a political program by Enlightenment political philosophers and politicians. But if the radical Enlightenment framed the break with the old regime as a generational break, perhaps this kind of presentism has since then indeed been the kind of inherent feature of modern democracy depicted by some political theorists today? Is it not possible that democracy was identified with radical temporal limits because this was, and is, in effect part of its structure? This is a possibility worth considering. Yet, it rests on the ahistorical presumption that democracy is a system or principle that is essentially stable over time. In the following, I instead attempt to examine the problem as one that has a history.

\section{Historicising democracy}

Any attempt to answer the question of whether democracy is presentist inevitably raises the issue of what democracy is. In the discussion in political theory on whether democracy has a problem with the future, and if so, what the causes and solutions for this may be, democracy is most often approached with theoretical tools from the analytic philosophical tradition, and identified by means of definitions and criteria. As an alternative and complement, I here suggest an approach to democracy as a historical phenomenon. This does not mean that democracy is a thing of the past, but 
rather that it must be understood historically. Drawing on historically oriented theorists, I will in the following point to what this could mean, and what it implies for the study of democracy, especially regarding the problem of presentism.

One way to approach democracy historically could be to regard it as a Wittgensteinian family resemblance in which no single trait or characteristic is shared by all members of the family of democracies, but they all resemble each other in some way (Biletzki and Matar, 2016; Mouffe, 2000: 62ff). This makes democracy a composite phenomenon. It also means that the different institutions and forms that appear in democracies have developed in different societies and historical contexts, and continue to do so. Therefore, democracy can be studied in its parts. A source from the past can be of interest for the study of democracy even if it was written by a person who would today not qualify as a democrat, or was created within a society that does not meet our standards of a democracy. The French 1830s is a case in point. The July monarchy would hardly qualify as a democracy today, even by the most generous criteria. In national elections, the franchise was for example restricted to a fraction of the male, propertied population (Guionnet, 1997: 10). ${ }^{1}$ In similar ways, the development of important elements of democratic rule and life are identifiable in 1830s France, such as the category of public opinion, and parliamentary culture and language (Wiese Forbes, 2010: xv; for a historical perspective on parliamentarism see Ihalainen et al., 2016, especially Palonen, 2016: 228). This was a period in which political conceptual and institutional solutions were tried out in quick succession, accompanied by a theoretical reflection that in many cases still counts as a major contribution to the history of democratic political thought (Ankersmit, 2008: 18).

Further, democracy is a type of rule in which practices of legitimisation play a central role. Quentin Skinner's approach that "what it is possible to do in politics is generally limited by what it is possible to legitimise" seems especially pertinent to democratic politics (Skinner, 1998: 105). Competing political languages or registers harbour different possibilities for legitimisation, thereby affecting what can be legitimised and thus what political measures are rendered possible. J. G. A. Pocock has described his project as "a wideranging investigation of the changing political languages in which societies talk to themselves" (Pocock, 2009: 89). The competing political languages set the stage differently as they - in different ways - delimit what can be done. The conflicts between different languages of legitimisation are typically concentrated in conflicts over particular concepts.

The fundamentally historical and political character of language contributes to the historical character of democracy (for an similar argument, see Ball, 2006: 11). Definitions of democracy inevitably contain political concepts. But if the large and rich field of historical research on political concepts is taken 48 
into account, political concepts are to be seen as arenas for political contestation and change, both synchronically and diachronically. ${ }^{2}$ Any definition of or criterion for democracy will therefore always be both historically specific and essentially contestable in character. (Haapala, Palonen and Wiesner and have made an analogous case regarding the concept of politics, arguing that the concept of politics has no ultimate definition since any definition is itself always an engagement in a political activity (2017: v)).

This means that a historical approach to democracy places political language and concepts at the centre of the enquiry. A historical understanding of temporal dimensions of democracy, such as presentism, therefore entails an enquiry into specific historical situations with attention paid to how different time frames have been conceptualised, legitimised and contested in different political languages. One such case is the concept of interest, a concept that is both highly contested and historical. It also often figures in political theoretical discussions of democracy's presentism. In this context, the concept of interest is most often used analytically, and ascribed a fixed meaning that does not include long-term aspects of society. As an example, Beckman argues that there is a conflict between the values of justice and democracy in matters of future generations, in the sense that "representing the interests of future generations in political decisions is not consistent with securing democracy for the living generation" (Beckman, 2013: 775).

From a historical perspective however, a concept such as that of interest is subject to change and contest, and as I argue in this article, it may well include, and has indeed included, long-term concerns. But as Dean Mathiowetz has argued, the historiography of the concept has often not taken this malleability sufficiently into account (for a critical overview of the literature on and historiography of the concept of interest, see Mathiowetz, 2011: 1-12). Mathiowetz argues that historians of the concept of interest have tended to project a late version of it back in time. This mistake naturalises the presumption that "interest is in essence calculating self-regard", although this in many instances is simply historically incorrect (Mathiowetz, 2011: 142-143). To the critique of the contemporary political-theoretical discussion of democracy's presentism, it could thus be added that not only is democracy treated ahistorically, but also key concepts related to it, such as interest.

In this article, I follow the conceptual historical perspective, shared by Mathiowetz, that there is no given or over-historical meaning to a concept like interest, but instead there are different uses of the word embedded in specific contexts. These uses are in turn tied up with various ideas about issues we understand today as fundamental human driving forces, the demarcation line between economy and politics, the epistemology of political truth, political representation, and forces of the market. Issues such as what interest means, whose interests are affected by a certain political measure, and what person 
or procedure is capable of identifying an interest, have historically been at the very core of political debates, not least for long periods of French history. During these periods, the concept of interest became a locus for contestation between competing political languages or registers for legitimisation. Interest is therefore a fitting case for a historical and conceptual approach to an important aspect of democracy.

In my suggested approach to democracy as a historical phenomenon it is therefore not the concept of 'democracy' itself that is examined, but the concept of "interest", intérêt in French, and the conflicting languages and political temporalities that have played out in that concept. In the following, I will attempt to historicise democracy by way of historicising interest as one of its core concepts. This can be regarded as a variation on Kari Palonen's suggestion that conceptual history can be thought of as a style of political theorising (Palonen, 2002).

\section{Liberalism and Popular Sovereignty as Competing Political Languages in 1830s and 40s French Forests Politics}

To historicise the question of democracy's alleged presentism by way of the concept of interest, we need a reasonably limited historical situation in which different political languages were mobilised on matters of the future (Ankersmit, 1996: 2-4; Palonen, 2002). To this end, I have chosen parliamentary debates on forest policy. Since trees grow slowly, managing and planning for forests readily and almost inevitably entails a long-term perspective. The forest issue will be studied in a period when several aspects of democracy went through qualitative developments, namely the latter part of the so-called "long revolution" (Matteson, 2015: 10) between 1789 and 1848 in French politics. The long revolution refers to the generally turbulent times in which fundamental political categories and institutions were being challenged, and which culminated in three revolutionary eruptions in 1789, 1830 and 1848. This article focuses on the latter part of this period, roughly between the passing of the new forest code in 1827 and the revolution in 1848. This period saw important developments and experimentation in areas of political forms, institutions, values and principles. It was also a time of a dynamic struggle between the two political languages of liberalism and popular sovereignty (Jainchill and Moyn, 2004: 134). Frank Ankersmit has pointed to the exceptional experimentation in conceptions of political representation during this period (Ankersmit, 2008: 18), and I argue that the spirit of experimentation is also a fitting description for the use of the political languages of liberalism and popular sovereignty. 
In matters of forest politics too, France had recently undergone important changes. Both the French revolution and the Napoleonic Code fundamentally altered the traditional relationship between nature and society. Successively the legislation replaced traditional usage rights and an understanding of the forest as a commons with private property laws. The 1827 Forest Code was a compromise between the state and private landowners, to the detriment of rural populations who often depended on the forests for their livelihood (Sarles, 2006: 573-4, 577-80). In many regions, people therefore continued their traditional use even after it was outlawed (Kalaora and Savoye, 1986: 20, 33; Whited, 2000: 22). In parts of France this led to conflicts, sometimes violent, between rural populations and the state's forest guards, and in some cases spectacular and carnivalesque acts of protest and resistance followed (Sahlins, 1994; Matteson, 2015).

The forest debate is not only pertinent for examining the problem of democracy's presentism since it actualises the question of the long term, it is also appropriate for another reason. Today's political theoretical debate on democracy's presentism is to a large degree spurred by the problem posed by climate change. In mid-19th century France, as in the rest of Europe, wood played an analogous role in the economy to that of fossil fuels today: wood was essential to almost all economic activity (Radkau, 2012), and the consequences of a political decision on forests would be palpable to people several generations into the future.

Parliamentary debate, which makes up the bulk of the material for this article, is a typical arena in which political possibility is created, negotiated, realised or blocked via contestation and deliberation by means of political language (Haapala et al., 2017: for example 1). In the enquiry conducted here, two competing political languages will be in focus, I call them liberalism and popular sovereignty. They are to be seen as two registers in which claims to legitimacy can be made. Neither of them is to be understood as normatively benign or democratic. I do however consider both to be significant aspects of democracy understood as a composite and historical phenomenon. ${ }^{3}$ This understanding also fits in with Pierre Rosanvallon's argument about democracy as having become more complex over time. Rosanvallon described this complexification as the development of modern political legitimacy, in the form of checks and balances to the simple rule of the majority (Rosanvallon, 2008: 26, 28). This identification of the two political registers can be seen as a variation of Andrew Jainchill and Samuel Moyn's description of the tumultuous turns of French political modernity. In their overview and analysis of Pierre Rosanvallon's œuvre, they summarise the latter's work in that it "defines the [French] revolutionary experience as fatally marked by the pathologies of both democratic voluntarism and rationalist liberalism". The 1830s and 40s saw "the triumph of elitist, rationalist liberalism over political voluntarism before the lat- 
ter's explosive return in 1848" (Jainchill and Moyn, 2004: 133-134). ${ }^{4}$ Further, the distinction between languages of liberalism and popular sovereignty is also related to analyses made at the time, for example Tocqueville's argument that popular sovereignty had illiberal tendencies that could turn it into a form of despotism (de Dijn, 2008: 143). As will become apparent, interest was a central concept both to the language of liberalism and that of popular sovereignty.

\section{The Concept of Interest and the Future: The 1830s}

In the practically serial debates on forest policy in the National Assembly during the 1830s, the main contestation over the concept of interest was structured as a conflict between a liberal and a popular sovereignty register of legitimisation. Repeatedly, the Assembly discussed and decided on the issue of how far-reaching landowners' liberties should be to cut down their forests as they wished, and under what circumstances the state should be able to restrict and regulate private forests. During the July monarchy, certain liberal principles were thoroughly protected, most importantly private property rights, and among them landowners' rights. The liberties of the press and opinion however soon lost the relatively strong position they held during the regime's first years (Wiese Forbes, 2010: xv). Although the dominating view was that forests were no different from other kinds of private property, it was not left uncontested, and the concept of interest became one of the main loci of this conflict. Issues of time and the future connected to the forest's slow temporality were raised by critics of the liberal concept of interest, but in the political debate of the 1830s, it was raised separately, and not integrated with the popular sovereignty register. At this point, the temporal critique did not rest on popular sovereignty-related grounds of legitimacy.

\section{The Liberal Concept of Interest}

The member of the National Assembly (député) most diligent in the forest policy debates of the 1830s was Alexandre-Jacques-Laurent Anisson-Duperron (1776-1852). ${ }^{5}$ His basic view was that self-interest (intérêt privé or particulier), if only left to operate freely, would have positive outcomes for society as a whole: "it is by doing our own business that we do the country's business" (Anisson-Duperron, 1835: 4). ${ }^{6}$ The alternative would mean to "substitute that which is the most clear-sighted in the world, the particular interest, with the cabinet's calculations and theories which, even if they are clever, are nevertheless refuted by experience every day" (Gauthier d'Hauteserve, 1834: 247). 
Benjamin Constant had advanced a similar understanding of the concept of interest twenty years earlier in his Principes de politique (1815). "What is the general interest", he wrote, "if not the transaction that takes place between the particular interests?” (Constant, 1815: 85 quoted in Hayat, 2011: 128). During the July Monarchy (1830-1848), many held a positive view of private interest as a societal driving force, but it was the dynamic of a plurality of selfinterests that was the crucial point. It was not legitimate to let one particular interest directly motivate political propositions. Calling a political proposal in the National Assembly an expression of private interest thus aimed at disqualifying it as a political issue.

The liberal concept of interest was part of a political language in which the protection of private property was an important principle. Anisson-Duperron declared that the question of forest clearings (défrichement) was an opportunity for him to "reclaim the free exercise of the rights of intelligence and property" which in his view had fallen behind the advancements of political liberty (Anisson-Duperron, 1835: 10). Property was conceptualised in terms of liberty (liberté de propriété), and it was a frequent trope that any person had the "freedom to use and abuse" his own property (see for example Jaubert, 1834, 725; Anisson-Duperron, 1835). The overall effect of this liberty would be beneficial to society as a whole. As Anisson-Duperron wrote in a report to the chambre des pairs: "private interest will create new tree plantations everywhere" (Dupleix de Mézy, 1834: 4). Any political effort to manage resources would fall short compared to the self-organising effects of free self-interest.

\section{Critique of the Liberal Concept}

The idea that general interest would appear out of all the added private interests (albeit with a few exceptions) was the dominant concept in the 1830s; but it was not uncontested. Anisson-Duperron's opponents instead regarded general interest as clearly separated from, often even opposed to, private interest. The conservative MP Raymond Duprat, for example, argued that the landowners, "blinded by their interest, [...] dispose of the conservation of their forests, in a way that essentially compromises the general interest" (Duprat, 1834: 721).

Many considered that it was an important task for the state to protect the general interest from different kinds of private interests. As Duprat phrased it, "it is the guardian action of the state, that watches over the general interest, that protects against the monopoly of those who abuse their rights, and makes a use of them that is contrary to the interest of all". In principle, general interest should prevail over self-interest (Duprat, 1834: 722-723). 
Many of the exponents of the liberal concept of interest however recognised that the principle of self-organisation wasn't perfect. For Anisson-Duperron, public safety was one concern that could not be satisfactorily safeguarded by the free pursuit of particular interests. In affairs that concerned public safety it was justified for the state to limit for example forest owners' property rights. It was however crucial that a concept like public safety was clearly defined to a limited set of cases, "such as the defence against the wind and the sand from the sea, the support for the soil or the supply of water to the wells on the tops or sides of mountains or close to the coast" (Anisson-Duperron, 1835: 13). These concerns were often referred to as being "in the general interest" (Barrachin, 1834: 250). It was however important that "liberté" was the principle, and limits to clear-cutting the exception.

This kind of critique of the privatisation of forests and the possibility of cutting it down freely is in line with the argument made by historians like Caroline Ford, Christophe Bonneuil and Jean-Baptiste Fressoz. That is, that already in the 19th century, an early kind of environmental consciousness was developing in France. As stressed by Ford, this consciousness was by no means an exclusive feature of naturalists and scientists, but a much broader phenomenon, "a number of initiatives were launched in both metropolitan and colonial France, which reflected a new environmental awareness that came to be expressed by government officials, politicians, writers, painters, and, most significantly, by the public or civil society at large" (Fressoz and Bonneuil, 2013: 95; Ford, 2016: 2). ${ }^{7}$ Both Ford, and Bonneuil and Fressoz thus cast doubt on the common notion that the modern environmental awareness awoke only in the 1960s.

Alongside the spatial critique presented by the opponents of unrestricted freedom of property, they also raised temporal concerns. For Duprat for example, the superior principle could not be that of freedom of private property. Instead, it should rest on the landowner who wanted to cut down his forest to convince the authorities that, in the case at hand, it was "unnecessary to conserve for the country a kind of consumer goods of which the reproduction is slow, the need general and the loss irreparable". The last point is crucial here, because it links the public or general character of the general interest to its long temporality. The forest's inherent slow pace is for Duprat the characteristic that constitutes its vulnerability, the reasons it calls for special protection by the state, "the destruction of forests is [...] immediate and complete, the need for fuel will be felt immediately" (Duprat, 1834: 722). As we will see, the notion that long-term concerns are constitutive of the general or public interest returned to the debate around 1848 .

For the MP Jean-Charles François de Ladoucette, a supporter of the Orléanist majority, the future was a concern of the same kind as the general interest, one that could not be reliably left to appear out of some other mechanism. 54 
The wisest people are those who "conserve on their territory everything necessary to satisfy all their needs, and who don't have to count on the good will of other powers to maintain their greatness, or on the mobile interests of exterior commerce". And this, de Ladoucette assures, should be of great interest to all "legislators who extend their foresight into the future" (de Ladoucette, 1835: 152).

Yet, liberal proponents of the correspondence between general and self-interest argued that the long-term effects on the forest in terms of "the interest of future supply", was no exception to the main principle (Anisson-Duperron, 1834: 1135). As put by one conservative MP in 1834, "the future is not compromised by some clear-cuttings" (Vérollot, 1834: 251). Long timespans such as the generations needed to produce timber did not change the fact that rising demand and prices would be enough incentive to prevent forest owners from harvesting too early. The interest of the individual forest owner was in accordance with the general interest. Forest owners were far-sighted, and new techniques for planting trees promised a great increase in productivity even in the present generation's lifetime (Gauthier d'Hauteserve, 1834: 248).

\section{Interest in the Language of Popular Sovereignty}

During the 1830s, the relationship between the liberal political language and the competing register of legitimisation, resting on popular sovereignty, was not symmetric. Although weaker, the latter still had its proponents. One was the centre-left MP Désiré-Joseph Véjux (1795-1857) who used a concept of interest that implied that the criterion for a general interest was the number of people holding it. It was the interest of the many, of the masses even, that was worthy of the Assembly's attention, and the general interest thus had to be calculated as the interests of the many, as opposed to something that was to emerge by self-organisation. In general, he argued, too little attention had been paid to the sacred intérêt des masses. As an example, Véjux argued, it was in the interest of the masses that the price of fuel didn't rise above a certain level. In matters of forests, the general interest was best protected by strict regulations, even if this meant that the forest owners' property rights were restricted (Véjux, 1835: 58).

Véjux argued for a specific definition of what should qualify as "considerations of public interest" and thus legitimate reasons for restricting forest owners' liberty. According to his suggestion, such considerations were cases in which the forest in question might have effects on "the support of soil; the alienation of wells that supply water for the inhabitants of a commune, village or hamlet; the defence against sand and wind from the sea, torrents 
and avalanches; other analogous cases" (Véjux, 1835: 58). Against this, an MP named Jean-Baptiste Teste, a supporter of the Orléanist majority, argued that specifying cases in this way was equivalent to "chaining the future" ("enchainer l'avenir"), an expression that echoed Rousseau's phrase that it would be absurd for the sovereign to "give itself fetters for the future" "il est absurde que la volonté se donne des chaînes pour l'avenir") (Rousseau, 1762: 49; Ritter and Bondanella, 1988: 99).

As in the case of the civil code, the specific cases calling for certain procedures would be better to leave some room for future interpretation of the law (Teste, 1835: 60). In this way, Teste argued for a concept of general interest that still pertains to the language of popular sovereignty, but in a different way than that of Véjux, namely a general interest that is open for negotiation in every new historical situation.

de Ladoucette also used the language of popular sovereignty to counter the liberal concept of interest. He defended Anisson-Duperron's proposal against the critique that it displeased the public opinion. The accusation that the proposal went against public opinion compromised the claim that it corresponded to the general interest:

if the clear-cuttings are so unfavourable to the general interest, which consists of particular interests, how come that these particular interests, that we have been assured are so enlightened as to their advantages, are opposed to the clear-cuttings? And if we face the question from a political point of view, should we make a law that is contrary to the public opinion? (de Ladoucette, 1835:152)

de Ladoucette here pointed to the public opinion as clashing with the aggregated self-interests, and used this clash to cast doubt on self-interest's status as wholly compatible with the general interest. He thereby questioned the benign self-organisation of freely exercised self-interest, and introduced public opinion as a possible counter-weight to it. This is a different argument from the one presented by Véjux, since it necessitates some expression of opinion from the public.

\section{The Concept of Interest and the Future: Around 1848}

In contrast to the 1830s debate, proponents of the popular sovereignty register of legitimisation made temporality and the long-term core to the concept of interest. As the 1830s turned into the 1840s, discontent with the increasingly repressive government of King Louis-Philippe I simmered. In terms of political language, political voluntarism rationalist and elite liberalism gave way to a register of popular sovereignty. References to the people, the masses, 
the many, the malheureux and the misérables came into ever more frequent use. During this time, the forest debate continued, and spread to the new specialised periodicals, such as Annales forestières and Le moniteur des eaux et forêts, both founded in 1842 . Tension continued to build until 1848 when protests broke out, the government had to resign and the Second Republic was established.

After the revolution in 1848 the interim government was short of money, it had trouble collecting taxes and renewing state bonds, and yet wanted to conduct large social projects, such as les atelier nationaux, state-funded workshops to provide work and mitigate the social crisis and unemployment (Corvol, 1987: 67-68). In March, the government decided to sell parts of the state forest that had earlier been governed as the king's property (a type of measure that had been executed under Louis-Philippe as well, Corvol, 1987: 68). This idea spurred a heated debate that took place in the National Assembly as well as in publications of different kinds. The conflicts over the forests also involved peasants, who saw a new opportunity to gain back the usage rights they had lost in the 1827 Forest Code (Matteson, 2015: 209). 1848 saw a new wave of protests against and attacks on state forest guards in France (Badre, 1983: 149; Ford, 2004: 180; Fortescue, 2005: 88).

\section{Interest in the Language of Popular Sovereignty: The Future as the True General Interest}

The plans to sell state forests were often motivated in a language of popular sovereignty, but were also met with criticism from opponents who employed the same register but for the sake of the long-term rather than the immediate needs of the people. One example of this is Joseph Humbert (1799-1868), a vicar in Lorraine and a diligent writer in the forest debate. Humbert explicitly challenged the view that "the general interest is nothing but the sum of all the private interests" and that it thus suffices to "give free rein to the private interests" in order for public interest to emerge (Humbert, 1849: 27). His main argument against this concept of interest was temporal: commodities whose production stretched out over longer periods of time could never be expected from private industries. Timber was here a case in point. Humbert sketched a diagnosis of the problem that in many ways resemble the problem of the tragedy of the commons, but with long-term temporality at the core. Although everyone would profit from there being enough timber to fulfil the needs of the navy no individual forester would grow it, however profitable, since there were faster ways of generating revenue on the land, particularly by growing coppice. The result would be timber scarcity, and once that was a 
fact, neither science nor private actors could offer any remedy. If any timber were to be produced, it would have to be protected by the state (Humbert, 1849: 26-30).

For Humbert, the blatant poverty in the cities alone proved the principle of freedom of property and the liberal concept of interest wrong. In the case of a city where more than 250000 citizens had less than 15 or 20 centimes a day to live on, he asked rhetorically, is it right to proclaim that thanks to the benefits of the industrial freedom, commodities were being manufactured "as it best suits the greatest interest of all?" (Humbert, 1849: 28).

Against those who, in the register of popular sovereignty, argued that it was in line with both the general interest and public opinion to sell state-owned forest to finance social policies, Humbert argued that when the government sold parts of the state's forest, this was always done against the "most evident and sacred interests of the greater part of the population", despite the government's claims to representative or democratic legitimacy (Humbert, 1847: 10). By this argument, Humbert implied that there was a "general interest proper" (intérêt bien entendu), a category distinct from the public opinion. In order for public opinion to align with the public interest, or the chose publique, certain conditions had to be met: sacrifices, for example, had to be shared equally.

By the way, no one ever wants to voluntarily support the sacrifices that the public affairs demand, as long as he knows that they don't weigh equally on all his fellow citizens. This is the reason why all the prohibitions of clear-cuttings have always only displeased the populations. The prohibitions infringe on the principle of equality recorded in our laws, without offering the advantage of safeguarding the public interest that they were there to favour in the first place (Humbert, 1849:30).

Picturing long-termism in relation to forests as an expression of the general interest was not a completely original trope in the late 1840s debate on forest policy. Léon Brisse (1813-1876), member of the committee for the liquidation of the royal property, described timber forests as distinctly separate from the aggregated self-interest. In matters of forests, "the personal interest can be subdivided in infinity, it often exists outside the general interest in a way that makes them almost impossible to reconcile". Some kind of long-term measure ("une mesure [...] prévoyante") had to be taken in order to resolve this contradiction (Brisse, 1848: 4). The interim government installed after the revolution in February of 1848 in Paris also described forests as a special case of general interest due to their particular time-scale. In a memorandum to the different départements, the minister of finance stated that "all devastation in the national forests, whoever causes it, is a crime against public affairs" and that "this crime is so much greater as it affects the general interest, not 
only in the present, but also in the future, as a century hardly suffices to replace a mature tree, that one hour of confusion can wipe out" (Duclerc, 1848: 573-574).

Humbert argued that the concern for the long term was at the very core of the "interest proper", but this interest was betrayed time and again. Humbert saw this as the consequence of human fault, and human fault had temporality at its core. Humans are often selfish and short-sighted. Like savages, he argued, they cut down the whole tree in order to get one of its fruits. "Facing a destructive egoism that cuts down the tree at the root, in the way of the savages, in order to pick its fruit, there are permanent social interests to defend, of which the government should be the natural protector" (Humbert, 1842: 320).

By that phrasing, Humbert echoed chapter thirteen in Montesquieu's De l'esprit des lois (1748) in which the author described the "idea of despotism" in the following way: "when the savages of Louisiana want fruit, they cut down the tree and gather the fruit. There you have despotic government" (Montesquieu, 1989 [1748]: 59). According to the historian Jeremy Jennings, Montesquieu by this anecdote first and foremost exemplified the lack of moderation in despotism, and its power imbalance (Jennings, 2011: 153). Humbert however used this passage to make a point about the lack of foresight as a conception of political illegitimacy, and of savagery. For him, the undermining of long-term maintenance, something we would perhaps understand as sustainability, is in itself a characteristic of despotism. (It is possible that the temporal aspect is in effect present already in Montesquieu's account of despotism, but this is not the place to find that out).

Short-sightedness was society's main problem, in Humbert's eyes: "If humans were immortal and acted only according to their proper interests, we could leave the field open for competition, but human life is precarious, even the longest is short" (Humbert, 1842: 320). The need to restrict the private, myopic interest was what made a strong state necessary. It was the role of the state to protect these "permanent social interests", something that Humbert argued that the state failed to do. He assigned the state the role of upholding a counter-logic to that of the market, and to protect resources like the forest for the common good and for future generations (Humbert, 1842: 320). This was necessary, as neither private business owners nor ordinary people could maintain a perspective beyond their own generation (Humbert, 1847: 6). This had to be done by the state, and selling state forests was thus seen as an anti-social act (Humbert, 1849: 31).

The reason for having the state manage forests is not only to prevent timber scarcity, but also because preserving forests affects "the virtues of the climate", "the conservation of wells" and offers an "insurance against floods". He classified these concerns in the category of public interest (Humbert, 1849: 30). 


\section{The Counted People Speaks}

The second example of a political language that includes the future in the general interest is articulated by Gustave Goldenberg, an agronomist and industrialist, mayor of Monswiller as well as conservative MP during the short-lived Second Republic (1849-1850). Alongside other debaters, Goldenberg argued for the reinstatement of customary law that allowed the rural population to use the forest as a commons. In a petition that he intended to send out to all maires de département in order for them to collect signatures to it, he suggested that "in the name of the poor and unhappy portion of the population", usage rights to the forest are reinstated in France (Goldenberg, 1848: 11). ${ }^{8}$ He underlined that it was crucial for future generations that the forest was managed intelligently, and this could only be achieved by making it in the interest of rural populations to look after and take care of it. And that could only be achieved by returning to using the forest as a commons. In its then current state, as private property, the condition of the forest and its future didn't matter to the populations living in and around it. On the contrary, private forests reinforced inequalities in society, since the poor constantly performed unpaid work that in effect increased the forest's value for the owner (Goldenberg, 1848: 17). For Goldenberg, interest was thus a constructed entity that could be changed by institutional arrangements, and should be so to the benefit of the people, in the sense of the many and the poor. Numbers mattered, but in contrast to the concept of general interest put forward by Véjux in the 1830s debate, Goldenberg underlined that those numbers had to express themselves, they could not just be identified from above.

Goldenberg's petition involved a conception of the people as a potential threat to the government if they were not involved in public affairs, and to the forest if they were not made interested in the forest's well-being. In contrast to Humbert's diagnosis of the forest problem, Goldenberg saw no conflict between generations. When used according to customary law, the forest's temporality was continuous and without generational conflicts of interest. Politically, the people were to be involved, their voices counted. "This participation of all is especially necessary under our republican regime, since what good would freedom be and why would we have so many means of communicating every idea among all the citizens, if a demand favourable to so many interests shouldn't receive the support and the signature of all interested" (Goldenberg, 1848: 2). What counts is the interest of the counted people. Goldenberg's version of interest was one closely intertwined with popular support. 


\section{Redescribing the People}

In their use of the popular sovereignty register, both Goldenberg and Humbert redescribed the people in relation to a well-established trope in the political vocabulary of the time. Especially in relation to forest, the people were often described as a destructive, short-sighted and chaotic force in the forest. Since just after the revolution, the narrative had prevailed that the people was always prone to pillaging and destroying the forests as soon as they got the chance. In certain circles, revolution had become practically synonymous with devastation (Whited, 2000: 25). This narrative was often put forward as evidence for the short-sightedness, lack of responsibility and political immaturity of the people, undermining the language of popular sovereignty. As we have seen, Humbert and Goldenberg both challenged this narrative, as did the 1848 revolutionary interim government. In a memorandum from the minister of finance to the different départements it was clearly stated that the people were not the main perpetrators of devastation, they were its victims: "[ $t]$ he populations that live next to the forest are the first to suffer from the plague that all devastation produces" (Duclerc, 1848: 574). If people were blind to the importance of protecting "that which safeguards their whole life", then that blindness could be overcome, and the rural population could be taught what the consequences were of the devastation they were engaging in. Ultimately, it was the law that could guarantee rights and protect the public interest in the shape of the forest (Duclerc, 1848: 575).

\section{Conclusions}

The enquiry into the case of interest shows how different uses of the concept of interest were entangled with different temporalities, more or less explicitly and consciously developed, and the conflict over that word was thus also a conflict over different temporalities. The political issue of forest management was at this time entangled with a serious and drawn-out social conflict between landowners and poor rural populations, between private property and the commons, and increasingly also between the urban and rural poor. The conflict between different temporalities was mediated through this social conflict but did not map on to it in any clear-cut manner. Instead it added another dimension of conflict, one that has not attracted as much interest from historians as the social and spatial dimensions.

The general pattern of a shift from the language of liberal to popular sovereignty as the dominant framework for legitimisation is not very surprising when we consider the radicalisation of French politics during this period. 
What is noteworthy is the way in which the popular sovereignty register includes and develops a sophisticated concern for future generations and the long-term in the concept of interest, and that this is done precisely with reference to the concept of the general interest. This concern is also in some cases underpinned by an anthropological argument about an inherent short-sightedness in humans which calls for political institutions, in this case the state, to protect long-term concerns.

This particular use of the concept of interest also went against the programmatic presentism of radical Enlightenment thinkers and revolutionaries of the late 18th century, as well as the revolutionaries in 1830, in which the trope of a revolt of the young against the old was inherent in the revolutionary political model (Sahlins, 1994: 119). Debaters like Humbert and Goldenberg redescribed the relationship between politics and the future in the sense that they advocated what they claimed to be the interest of the people while maintaining a transgenerational political temporality. This political register resonated with the revolutionary tradition, but broke with its presentism. Its proponents claimed that it was precisely in the name of the people that the long-term aspects of the general interest must be protected, and thereby established the possibility of integrating a concern for the future in the political language without being politically conservative.

This episode in the history of the concept of interest shows that already in cases like Humbert and Goldenberg a programmatic presentism that equated political renewal with generational breaks was contradicted via such moves as a redescription of the people. They actively countered the disregard for long-term perspectives that had dominated the forest debate, and did so by strategically using the concept of interest. They also mobilised other concepts central to the composite phenomenon of democracy, such as the people.

\section{What Can a Historical and Language-Centred Perspective Contribute?}

In this article, I have suggested that if we regard democracy as a fundamentally historical phenomenon, its temporal structure, such as presentism, is less to be understood as inherent properties and rather as changing characteristics that are to be examined historically, by enquiries into specific cases (this argument is similar to the one made by Lefort, 1993: 6). I suggested the concept of interest as one possible such case, as it has functioned as a locus for contest between competing political languages as frameworks of legitimacy, and also of competing temporalities. 
The concept of interest often plays an important part in political theoretical discussions of the problem of democracy's presentism. It is then understood in a way that disregards long-term concerns. This use of the concept of interest presupposes presentism. One such example is Beckman's discussion of how the values of justice and democracy clash on the issue of future generations in politics, "[r]epresenting the interests of future generations in political decisions is not consistent with securing democracy for the living generation" (Ludvig Beckman, 2013). Trying to represent the interest of future generations in democracies gives rise to an important conflict of interest (Beckman, 2015: 534). Further, when democratic inclusion is discussed in terms like "[a]nyone whose interests are affected by the government of a country should have the right to vote" (Dobson, 1996: 124) it also presupposes that interest is a stable - and thus ahistorical - category in the sense that it can be conclusively determined what somebody else's interest is, and that time is not going to affect it. (For a thorough and historically informed critique of the role of the concept of interest in political theory, see Mathiowetz (2011)).

Contrary to this presentist presupposition, the history of the concept of interest suggests that issues such as what is meant by interest, what person or procedure can identify an interest, and thus whose interests are indeed affected by a certain policy, are subject to both synchronic contestation and diachronic change. Far from a fixed meaning that disregards long-term concerns, the history of the concept of interest includes radical redescriptions of it that take the well-being of future generations into account, or a management of resources that secures against depletion over time. As the examples from 1848 show, it is also possible to advance an understanding of the concept of interest as one in which the burdens of preserving limited resources for the future are distributed equally among the living. In the 1840s, the non-presentist understandings of the concept of interest were also closely intertwined with other aspects of the composite phenomenon of democracy, such as public opinion, popular support, the people etc.

What does this understanding of the concept of interest entail for the problem of democracy's alleged presentism? The empirical case examined here suggests two things. First, it points to an important counter-example to the presentism often asserted as inherent or necessary to democracy. Second, it underlines the malleable and constantly conflicted nature of the concept of interest as well as of democracy's languages of legitimisation at large (Dean Mathiowetz (2011: 142-145) presents a parallel argument in his discussion of an enlarged and historically informed concept of interest). Moving away from seeing a concept like interest as having a fixed and timeless meaning is part of an understanding of democracy as not inherently presentist, but a political form that has harboured practices of legitimising both radical presentism and elaborate long-term perspectives. Rather than looking for the problem within 
democracy as a system, efforts to counter presentism could then be directed at consciously influencing current frameworks of legitimacy by redescribing concepts and remoulding languages. This can be regarded as a continuation of the development of legitimacy that Rosanvallon describes as a complexification of democracy, and of which the diversification of democracy's temporalities is an important part (Rosanvallon, 2008: 209-211).

In an argument that in several ways resembles the conceptual historical understanding of democracy, political theorist Robyn Eckersley has also pointed to the potential of deliberation for expanding the concerns of democratic politics. Political deliberation can promote an enlarged thinking that includes for example concern for future generations in the political sphere (Eckersley, 2000: 120-121). Michael Saward has presented a similar argument about the potential of deliberation to enable citizens to conceive of and incorporate the interests of, for example, future people into accounts of their own and their communities' interests (Saward, 2008: 15). Promoting an enlarged thinking could be a fitting label for what certain debaters and MPs tried to accomplish in the French 1840s, when they tied human short-sightedness and the societal need to counter that into the political debate on forest politics.

Eckersley further argues that theories of deliberative democracy understand political language in a more benign way than theorists of liberal democracy, stressing language's "other-regarding" potential in contrast to "the 'distorted' and 'strategic' political communication" implied in theories of liberal democracy. The "power trading between self-interested actors" can be replaced by a more open-ended understanding of what values should be pursued in the public sphere (Eckersley, 2000: 120-121). I understand Eckersley's argument to be in line with a refutation of a fixed - I would say ahistorical - understanding of democratic politics, in favour of a more malleable political sphere in which fundamental categories such as who the actors are, what their driving forces are and what matters of political concern can possibly be, are open questions that can be influenced by a conscious use of political language.

Joan Scott has shown how 19th century feminists used language in a similar way when they challenged the exclusion of women by "an almost uncanny ability to sniff out and exploit ambiguities in the foundational concepts of philosophy, politics and common sense". In different ways, they employed the concept of woman strategically in relation to the concept of the individual, and thereby attempted to point out what they saw as a systematic betrayal of the universal principles of freedom, equality and brotherhood. But they went one step further, and tried to offer a corrective to this betrayal "by demonstrating that they, too, were individuals according to the standards of individuality of their day" (Scott, 1996: 11-13).

In an analogous way, consciously cultivating the use and thus the content of concepts such as interest could be a way of "enlarging our thinking", in 64 
Eckersley's terms, in a way that could include long-term concerns and counter presentism in contemporary democracies, and offer a corrective in the way of Scott's French feminists. Strategically forging fundamental concepts such as interest is a way of influencing the topography of legitimacy and thus ultimately influencing what can be done in politics. Political language is a democratic resource that can offer a strategy for getting out of, or mitigating, frameworks prone to presentism in contemporary democracies, especially regarding issues of climate and the environment. History can inform such strategies by offering examples of what resources were drawn upon in the past to include longterm concerns in the concept of interest. In the French 1840s, the language of popular sovereignty turned out to be a resource that was possible to mobilise in attempts to legitimise long-term perspectives. Unpacking a concept like interest by historical investigation thus calls into question presentist assumptions about interest in our own time. This in turn opens the way for uses of the concept that include long-term concerns and thus unlocks the framing of issues like climate change.

\section{Endnotes}

1 On the local level however, the July monarchy was more progressive. In 1831, municipal elections were institutionalised that enfranchised ten times as many (male) voters as in the national elections. (Guionnet, 1997: 10).

2 In this article, I draw on the methodological work developed within both the Cambridge and Bielefeld schools of conceptual analysis, with Quentin Skinner and Reinhart Koselleck as their respective figure heads. The combination of the two schools has been theorised and methodologically synthesised by Jordheim (2003) and Palonen (2002).

3 The two languages are not an exclusive list; based on both the historical sources and scholarly literature, I would point to at least one more political language of significance, namely the language of political representation. For the purposes of this analysis, the languages of liberalism and popular sovereignty will however be most useful, since they are most clearly distinguishable from each other.

4 It should be noted that the "triumph of elitist, rationalist liberalism" in Jainchill and Moyn's /Rosanvallon's account starts already in 1814. See also Samuel Hayat's argument about the two opposing conceptions of the republic that followed the revolution in 1848 (Hayat, 2014: 21-24).

5 All information about the biographies and political careers of French members of parliament come from the Base de données des députés français depuis 1789 at the website of the Assemblée Nationale. http://www2.assemblee-nationale.fr/sycomore/recherche.

6 Unless otherwise indicated all translations are mine.

7 It is worth noticing that Fressoz and Bonneuil place the emergence of this environmental consciousness earlier than Ford does. According to them, deforestation 
became the object of an important debate and development of a consistent tradition of thought as early as the 1770 s.

8 Political events unfolded more quickly than Goldenberg had predicted, and the suggested selling of state forests that he criticised was stopped before the petition was printed.

\section{References}

ANKERSMIT, Frank, 2008. Representative Democracy: Rosanvallon on the French Experience. In Kari Palonen, Tuija Pulkkinen and José María Rosales (eds.), The Ashgate Research Companion to the Politics of Democratization in Europe: Concepts and Histories. London, New York: Routledge, 17-36.

BADRE, Louis, 1983. Histoire de la forêt français. Paris: Arthaud.

BALL, Terence, 2006. Must Political Theory be Historical. Contributions to the History of Concepts, 2:1, 7-18.

Base de données des députés français depuis 1789, Assemblée Nationale. http://www2.assemblee-nationale.fr/sycomore/recherche.

BECKMAN, Ludvig, 2008. Do Global Climate Change and the Interest of Future Generations Have Implications for Democracy?. Environmental Politics, 17:4, 610-624.

BECKMAN, Ludvig, 2013. Democracy and Future Generations. Should the Unborn Have a Voice?. In J.-C. Merle (ed.), Spheres of Global Justice: Volume 2: Fair Distribution: Global Economic, Social and Intergenerational Justice. Dordrecht: Springer Science + Business Media, 775-788.

BECKMAN, Ludvig, 2015. Political Representation of Future Generations and Collective Responsibility. Jurisprudence, 6:3, 516-534.

BILETZKI, Anat and Anat Matar, 2016. Ludwig Wittgenstein. In Edward N. Zalta (ed.), The Stanford Encyclopedia of Philosophy. https://plato.stanford.edu/archives/ fall2016/entries/wittgenstein/.

BURKE, Edmund, 2001 [1790]. Reflections on the Revolution in France: A Critical Edition. J. C. D. Clark (ed.). Stanford: Stanford University Press.

CONSTANT, Benjamin, 1815. Principes de politique applicables à tous les gouvernements représentatifs et particulièrement à la constitution actuelle de la France. Paris: A. Eymery.

CORVOL, Andrée, 1987. L'homme aux bois: Histoire des relations de l'homme et de la forêt, XVIIe-XX siècle. Paris: Fayard.

DE DIJN, Annelien, 2008. French Political Thought from Montesquieu to Tocqueville: Liberty in a Levelled Society?. Cambridge: Cambridge University Press.

DOBSON, Andrew, 1996. Representative Democracy and the Environment. In William Lafferty and James Meadowcraft (eds.), Democracy and the Environment: Problems and Prospects. Cheltenham: Edward Elgar, 124-139.

ECKERSLEY, Robyn, 2000. Deliberative Democracy, Ecological Representation and Risk: Towards a Democracy of the Affected. In Michael Saward (ed.), Democratic Innovation: Deliberation, Representation and Association. London, New York: Routledge, 117-132. 
FECHNER, Erik, 1987. L'arbre de la liberté: objet, symbole, signe linguistique. Mots, 15, 23-42.

FORD, Caroline, 2004. Nature, Culture and Conservation in France and Her Colonies 1840-1940. Past \& Present, 183:1, 173-198.

FORD, Caroline, 2016. Natural Interests. Cambridge, Mass.: Harvard University Press.

FORTESCUE, William, 2005. France and 1848: The End of Monarchy. London, New York: Routledge.

FRESSOZ, Jean-Baptiste and Christophe Bonneuil, 2013. L'Evénement Anthropocène: La Terre, l'histoire et nous. Paris: Editions du Seuil, 95.

GARDINER, Stephen M., 2014. A Call for a Global Constitutional Convention Focused on Future Generations. Ethics \& International Affairs, 28:3, 299-315.

GONZÁLEZ-RICOY, Iñigo and Axel Gosseries (eds.), 2016. Institutions for Future Generations. Oxford: Oxford University Press.

GUIONNET, Christine, 1997. L'apprentissage de la politique modern: Les élections sous la Monarchie de Juillet. Paris: l'Harmattan.

HAAPALA, Taru, Kari Palonen and Claudia Wiesner, 2017. Debates, Rhetoric and Political Action: Practices of Textual Interpretation and Analysis. London: Palgrave Macmillan.

HAYAT, Samuel, 2011. “Au nom du peuple français" La représentation politique en question autour de la révolution de 1848 en France. Doctoral thesis, Université Paris 8, Saint-Denis.

HAYAT, Samuel, 2014. 1848: Quand la République était révolutionnaire: Citoyenneté et representation. Paris: Editions du Seuil.

HUNT, Lynn, 1992. The Family Romance of the French Revolution. Berkeley: University of California Press.

IHALAINEN, Pasi, Cornelia Ilie and Kari Palonen (eds.), 2016. Parliament and Parliamentarism: A Comparative History of a European Concept. New York, Oxford: Berghahn.

JAINCHILL, Andrew and Samuel Moyn, 2004. French Democracy between Totalitarianism and Solidarity: Pierre Rosanvallon and Revisionist Historiography. The Journal of Modern History, 76:1, 107-154.

JAUME, Lucien, 1992. Les Jacobins et Rousseau. Commentaire, 60:4, 929-936.

JENNINGS, Jeremy, 2011. Revolution and the Republic: A History of Political Thought in France since the Eighteenth Century. Oxford: Oxford University Press.

JORDHEIM, Helge, 2003. Läsningens vetenskap: utkast till en ny filologi (transl. Sten Andersson). Gråbo: Anthropos.

KALAORA, Bernard and Antoine Savoye, 1986. La Forêt Pacifiée: Les Forestiers de l'Ecole de Le Play, Experts des Sociétés Pastorales. Paris: Editions l'Harmattan.

KEANE, John, 2016. A New Politics of Time. The Conversation, 2, [https://theconversation.com/a-new-politics-of-time-69137].

LEFORT, Claude, 1993. L'incertitude démocratique. Revue européenne des sciences sociales, 31:97, 5-11.

MÅRALD, Erland and Erik Westholm, 2016. Changing Approaches to the Future in Swedish Forestry, 1850-2010. Nature and Culture, 11:1, 1-21.

MATHIOWETZ, Dean, 2011. Appeals to Interest: Language, Contestation, and the Shaping of Political Agency. University Park, Pa.: Pennsylvania State University Press. 
MATTESON, Kieko, 2015. Forests in Revolutionary France: Conservation, Community, and Conflict, 1669-1848. New York: Cambridge University Press.

MONTESQUIEU, Charles-Louis de Secondat, 1989 [1748]. The Spirit of the Laws (transl. and eds. Anne M. Cohler, Basia Carolyn Miller and Harold Samuel Stone). Cambridge: Cambridge University Press.

MOUFFE, Chantal, 2000. The Democratic Paradox. London: Verso Books.

NEDEVSKA TÖRNQVIST, Jasmina, 2010. An Environment Worthy of Future Generations: A Thomist Run for Justice. Unpublished Master's Thesis, Department of Government, Uppsala University.

NORA, Pierre, 1992. Les lieux de mémoire 3:1. Paris: Gallimard.

PACINI, Giulia, 2016. Arboreal Attachments: Interacting with Trees in Early Nineteenth-Century France. Configurations, 24:2, 173-195.

PAINE, Thomas, 1996 [1791]. Rights of Man. Hertfordshire: Wordsworth Editions.

PALONEN, Kari, 2002. The History of Concepts as a Style of Political Theorizing: Quentin Skinner's and Reinhart Koselleck's Subversion of Normative Political Theory. European Journal of Political Theory, 1:1, 91-106.

PALONEN, Kari, 2016. Thinking of Politics in a Parliamentary Manner: Perspectives on the Conceptual History of Parliamentarism. In Pasi Ihalainen, Cornelia Ilie and Kari Palonen (eds.), Parliament and Parliamentarism: A Comparative History of a European Concept. New York, Oxford: Berghahn, 228-242.

PARNES, Ohad, Ulrike Vedder and Stefan Willer, 2008. Das Konzept der Generation: Eine Wissenschafts- und Kulturgeschichte. Frankfurt am Main: Suhrkamp.

POCOCK, John Greville Agard, 2009. Political Thought and History: Essays on Theory and Method. Cambridge: Cambridge University Press.

RADKAU, Joachim, 2012. Wood: A History (transl. Patrick Camiller). Malden: Polity Press.

RITTER, Alan and Julia Conaway Bondanella (eds.), Rousseau's Political Writings (transl. Julia Conaway Bondanella). New York: W.W. Norton.

ROSANVALLON, Pierre, 2008. La légitmité démocratique: Impartialité, reflexivité, proximité. Paris: Editions du Seuil.

ROSANVALLON, Pierre, 2014. Le souci du long terme. In Dominique Bourg and Augustin Fragnière (eds.), La pensée écologique: Une anthologie. Paris: Presses Universitaires de France, 835-844.

ROUSSEAU, Jean-Jacques, 1762. Du contrat social ou Principes du droit politique. Amsterdam: Marc Michel Rey.

SAHLINS, Peter, 1994. Forest Rites: The War of the Demoiselles in Nineteenth-Century France. Cambridge, Mass.: Harvard University Press.

SARLES, Curtis, 2006. The Instatement of Order: State Initiatives and Hegemony in the Modernization of French Forest Policy. Theory and Society, 35:5/6, 56585.

SAWARD, Michael, 2008. Constituting Sustainability. The Good Society, 17:2, 12-17. SCOTT, Joan Wallach, 1996. Only Paradoxes to Offer: French Feminists and the Rights of Man. Cambridge, Mass.: Harvard University Press.

SKAGEN EKELI, Kristian, 2005. Giving a Voice to Posterity: Deliberative Democracy and Representation of Future People. Journal of Agricultural and Environmental Ethics, 18:5, 429-450. 
SKAGEN EKELI, Kristian, 2006. The Principle of Liberty and Legal Representation of Posterity. Res Publica, 12:4, 385-409.

SKINNER, Quentin, 1998. Liberty before Liberalism. Cambridge: Cambridge University Press.

THOMPSON, Dennis F., 2005. Democracy in Time: Popular Sovereignty and Temporal Representation. Constellations, 12:2, 245-261.

THOMPSON, Dennis F., 2010. Representing Future Generations: Political Presentism and Democratic Trusteeship. Critical Review of International and Political Philosophy, 13:1, 17-37.

VELICU, Adrian, 2010. Civic Catechisms and Reason in the French Revolution. Farnham: Ashgate.

WHITED, Tamara L., 2000. Forests and Peasant Politics in Modern France. New Haven: Yale University Press.

WIESE FORBES, Amy, 2010. The Satiric Decade: Satire and the Rise of Republicanism in France, 1830-1840. Lanham: Lexington Books.

WILLER, Stefan, 2011. A Concept of Transfer - Transfers of a Concept: Generation in Physiology, Pedagogy, and Politics around 1800. Contributions to the History of Concepts, 6:2, 69-84.

\section{Primary Sources}

ANISSON-DUPERRON, Alexandre-Jacques-Laurent. Chambre des députés, 3 May, 1834, Le Moniteur universel, 4 May, 1834, 1135.

ANISSON-DUPERRON, Alexandre-Jacques-Laurent, 1835. Chambre des députés, 15 December, 1834, №17. Développemens de la proposition de M. Anisson-Duperon, Député de la Seine-Inférieure, Sur le Défrichement des Forêts. Paris: A. Henry.

BARRACHIN, Augustin, Chambre des députés, 8 March, 1834, Archives Parlementaires de 1787 à 1860, Série 2, T.87, Jérôme Mavidal and Emile Laurent (eds.), Paris: Dupont, 1894, 250.

BRISSE, Léon, 1848. Exposé de la méthode sylvicole employée au repeuplement des vides et clairières de la forêt de Montrichard (Loir-et Cher). Saint-Germain: Imprimérie de Beau.

DE LADOUCETTE, Jean-Charles François, Chambre des députés, 21 January, 1835, Le Moniteur universel, 22 January, 1835, 152.

DUCLERC, E., 1848. No 383. Circulaire du ministre des finances aux commissaires des départements pour empêcher les dévastations des bois et forêts, Paris, 13 avril 1848. In Émile Carrey (ed.), Recueil complet des actes du Gouvernement provisoire (février, mars, avril, mai 1848): avec des notes explicatives, des tables chronologiques et une table alphabétique, analytique et raisonnée des matières. Paris: A. Durand, 573-575.

DUPLEIX DE MÉZY, Charles-Joseph-René, 1834. Chambre des Pairs. 22 May, 1834, N¹20. Rapport fait à la Chambre par M. Dupleix de Mézy, au nom d'une commission spéciale, chargée de l'examen du Projet de loi portant modification aux articles 219 et 220 du Code forestier, relatifs au défrichement des bois. Paris: Imprimérie de Crapelet. 
DUPRAT, Raymond. Chambre des députés, 3 May, 1834, Archives Parlementaires de 1787 à 1860, Série 2, T.89, Jérôme Mavidal and Emile Laurent (eds.), Paris: Dupont, 1894, 721-723.

GAUTHIER D'HAUTSERVE, Edme Bernard, Chambre des députés, 8 March, 1834, Archives Parlementaires de 1787 à 1860, Série 2, T.87, Jérôme Mavidal and Emile Laurent (eds.), Paris: Dupont, 1894, 247-248.

GOLDENBERG, Gustave, 1848. Pétition présentée à l'Assemblée nationale pour obtenir la révision du code forestier, en ce qui concerne les droits et jouissances dans les forêts, la modification de la pénalité, ainsi que l'abrogation de quelques abus de l'administration forestière. Strasbourg: Imprimérie de G. Silbermann.

HUMBERT, Joseph, 1842. Observations de M. Humbert. Le moniteur des eaux et forêts, 7, 319-323.

HUMBERT, Joseph, 1847. Quelques considérations sur les excès du déboisement et sur le projet de reboisement, reproduites en vue de la modification que doit subir la loi forestière, dans la session législative de 1847. Nancy: Imprimérie de Vagner.

HUMBERT, Joseph, 1849. Quelques réflexions sur l'aliénation des forêts de l'État. Annales forestières, T.8, 25-33.

JAUBERT, Chambre des députés, 3 May, 1834, Archives Parlementaires de 1787 à 1860, Série 2, T.89, Jérôme Mavidal and Emile Laurent (eds.), Paris: Dupont, $1894,725$.

TESTE, Jean-Baptiste. Chambre des deputes, 22 January, 1835, Archives Parlementaires de 1787 à 1860, Série 2, T.92, Jérôme Mavidal and Emile Laurent (eds.), Paris: Dupont, 1895, 60.Véjux, Désiré-Joseph, Chambre des deputes, 22 January, 1835, Archives Parlementaires de 1787 à 1860, Série 2, T.92, Jérôme Mavidal and Emile Laurent (eds.), Paris: Dupont, 1895, 58.

VÉROLLOT (Vérrollot), Louis Vulfranc, Chambre des députés, 8 March, 1834, Archives Parlementaires de 1787 à 1860, Série 2, T.87, Jérôme Mavidal and Emile Laurent (eds.), Paris: Dupont, 1894, 251. 